\title{
Significant Issues for the Future of Product Innovation
}

\author{
With Contributions From: \\ C. Merle Crawford \\ Emeritus Professor of Marketing, The University of Michigan \\ Milton D. Rosenau, Jr., CMC \\ President, Rosenau Consulting Company
}

In this issue, Merle Crawford and Milton Rosenau present their thoughts on some of the issues confronting product development professionals. Both reflect on the emergence of new products management as a profession-a field with its own requirements for success. Crawford wonders about the sustainability of our current use of teams for much of our work, the need for improved measurements, and the overall relationship between the management of new initiatives and the ongoing work of the organization. As new products work become more integrated with corporate operations, what new responsibilities will we face, beyond our current challenges? Rosenau looks squarely at the complex issues of rewards and compensation. How can we modify systems that have traditionally evaluated individual performance and adjust them to fit various cooperative work patterns necessary in new product development? He calls for formal study of these important issues. These essays continue a year-long series of contributions that the editor-in-chief solicited from members of the editorial board. Members were asked to reflect on changes and opportunities that they feel will influence our profession during the coming decade. Both of these short essays are designed to introduce new perspectives. It is not essential that you agree with the recommendations, but we hope that you are stimulated as you reflect on the issues that are raised.

\section{We Should Be Proud, But Not Satisfied}

\section{Merle Crawford}

Amidst the noise of productive and exciting product innovation today, I sense a certain spinning of wheels and happiness in simplicities. Teams, teams, teams-a concept at least two generations old and history already. Buzz words worshipped more than evaluated and challenged. Our overall progress may be hiding some problems that I want to address, with the twin caveats of essay writers: I have too little space and thus offer too little proof of evidence.

I will ask about implications of current events, our tendency to avoid practicing what we preach, and our alarming avoidance of the responsibilities of success.

1. What are the implications of current events? Teams abound and grow. But what happens when our paucity of trained leaders and team members runs out? One cannot expect an unlimited supply of good members once we field scores and hundreds of teams in an individual firm. A shortage will cause the next turn of the organization wheel, and I hope we take time to wonder what that might be-perhaps some system of modular team components buttressed by another set of modular support functions? We need a way to break them into smaller pieces, for efficient use/nonuse periods, to say nothing of devising ways teams themselves are managed, as a group.

Empirical research has also yet to address the tough issue of under what conditions does the cross- 
functional team break down? A recent story on a new pharmaceutical at Upjohn suggests that, under FDA regulations, the functional "silos" had better be strong. Another story told is of 3M's new love for teams, but we must wonder how they handled the firm's necessarily powerful staff departments of law, safety, environment, and more.

It seems we may not have escaped a long-time need for every firm to have at least one very strong function that actually permits the team to succeed. Could a packaged goods firm have successful new products without capable brand management? Could a powergenerating Westinghouse operate without top people in engineering? And why do many team success stories involve what I call Black \& Decker products, which appear not to need a single-function strength? Frankly, can we prove there really is "team" success? Maybe we have charismatic team leaders who would have succeeded in any organization format.

A parallel issue concerns the management of the ongoing, established business. What happens to that when its key planners have been attracted to new ventures? Lately, consultants have been encouraging "flooding," flooding the market with minor product variations. But managed by whom? How much longer before managers who keep the shop open find a way to let their frustrations be known?

Another struggle is probably closer-that between upper management and middle management over direction of teams. In pro sports, owners fight with players, and managers and coaches struggle both ways. $3 \mathrm{M}$ now assigns a sponsor to each team-does anyone really think this is just a service to aid the team?

Yet another struggle will be the worst, last the longest, and perhaps do more to change corporate organization than all of the above. This is the struggle between functional team members. We expect them to be afunctional eunuchs, dedicated to the team not the function. This, of course, is preposterous except in very rare cases. We still live in a matrix world. Functional fighting will almost certainly increase as team players learn how to appear cross-functional while scheming to gain power for their function.

The newer players (manufacturing and more recently human resources) seem to have just discovered product innovation and are building their own experience and wisdom, refusing in most cases to learn from those who have been in the game for some time. But both of their roles, along with those of technical and marketing personnel, are essential. There just is not room for four people at the head of the table.
The field risks fragmentation unless we can strengthen the core against the pull of the disciplines. We already have trouble communicating, as for instance when manufacturing and technical groups claim to have good data on cycle times; these are their cycle times, on the technical parts of the new product process. Sadly, one best begin well ahead of that, and keep working long after the boxes land on the shipping dock. I have not seen a forecasted "cycle time" when it includes the entire task, and even management can not just order up an initial one (of their liking) since technical feasibilities are usually at issue.

This leads to a different set of concerns, those based on our very poor system of measurement. We run well behind the rest of the firm on quality management. We have few usable metrics, either on inputs (activities) or outputs (results and accomplishments), and few standards for comparison when we do get a measurement.

Keep in mind that we are talking about our processes, not products, so where are the satisfaction data? My impression is that very few managements know how well their product innovation function is being managed. They do not know what it costs, and what it actually produces, and they ignore the most critical cost of all-opportunity costs. We can add up salaries and expense budgets, and we can calculate profits and ROIs on the new products produced, but surely no one would suggest that top managements and stockholders depend on such incomplete data. Given that personnel from both new and established programs contribute to any overall appraisal done, we are back to sharing, and blaming.

Speaking of measurement, where is the measurement of methods, as they are proposed in our literature and at our conferences? We cannot expect quantitative evidence for any recommendation until we learn to measure the action. Nor can a critic yell "junk," without data. We simply cannot claim to be doing a good job (or confess to a poor one) when we really do not know.

So, we suffer no measures of quality, no measures of satisfaction by managements, and no measures of effectiveness of individual methods and tools. Will we really go to work studying our overall process only when an equivalent of the immense competitive pressures created by the Japanese auto companies forces us to?

The remaining issue under the topic of implications from current practice concerns consultants (business, academic, inside staff). We should be very proud of the 
ones working product innovation-they are doing outstanding things in association management, in conference speeches, and in their writing (without which most business publications would suffer.) But, are we asking what this leads to? Not all consultants are competent or have a solid sense of their responsibility to a willing constituency. Not all editors or conference planners have the richness of speakers to be selective.

As a text author I watch consultants closely-they have new ideas, and are good communicators. They have access to places where change is taking place. But, to drop the other shoe, should we let ourselves depend on them, can they be unbiased on these matters, are they the first set of human beings to be free of hidden agenda? Are we letting slide our responsibilities? In fairness, these same questions need to be asked of all participants in the field of new products, from wherever they come.-which leads into the second major topic.

2. Are we practicing what we preach? We are building one of the most powerful process capabilities in business history-actually a new "product." But what strategy guides this effort? What kind of charter is there for those working on this project? Are they a team, and how are they to function? What are their objectives, what is their technology/market focus (e.g., are we simultaneously developing process/people for development in nonprofit fields?)? What is their funding, and where is their phased development process? Are we guilty of rushing to prototype, so often a weakness in services?

Our guilt by omission is clear. We are actively creating this new "machine" yet we have no management of the creation process. I do not think we can fault business or government for not funding the type of direction and research we really require. To my knowledge they have not been asked.

The fact is, I suppose, that the new products field is growing like Topsy, slowly but successfully so far. Before we default to others, perhaps we should begin acting like the winner, and key player, that we have become-which leads into the third point.

3. If we have the power to produce new products that can solve virtually every corporate problem (competition, costs, whatever) what new responsibilities go with this power? Said differently, now that they let us come to the party, are we going to learn how to behave? We certainly can, but perhaps we don't see the need.
We might begin by inquiring about the role of product innovation in an organization. What do we owe management and owners by way of quality control on personnel-entry qualifications, and discipline? The silo heads require that their people have prior training and evidence of performance before they are hired or promoted. But we have no common standards for new product work, and training may last only a few minutes or hours. Medicine has its Hippocratic Oath, engineering has its PE code, and marketing people have a code of ethics. Do we not have some obligation along these lines too? This is one very powerful set of tools we use; are we up to taking care that they are well used?

A second line of inquiry leads to the sputtering diffusion of our knowledge? We have been doing better these past few years, but the general level of knowledge of product innovation techniques among people in business and academia is deplorable. They want to know, but is the burden on them to find our knowledge? Moreover, are we free of obligation to identify any aspect of our task that we do not understand and perform well? Management may be assuming that we address the really tough questions in our new profession, such as with a brain trust, or a think tank, or a senior advisory board.

On a more personal scale, where is our outrage, outrage at inefficiency and incompetence, missed opportunities to serve, and garbage pushed as accomplishment? When we suffer poor publications, poor conferences, poor whatever, who speaks out? We need to find a way to react meaningfully when a firm that is what we must call "new products incompetent" announces the discovery of a new technique that has been in use for 20 years, successfully and openly. Why is it still popular to start new product articles with the claim that $80-90 \%$ of new products fail, and rare that anyone complains about such statements? We have not even informed the editors.

A closing thought. My comments have been those of a member of this grand new profession of new product personnel, even though I am an academic. Academe is important to a profession, but our educational establishment must ask what have we done to keep brilliant thinkers and conceptualizers thinking and conceptualizing, rather than consulting. PDMA can be proud of its joint business and academic nature, but as academics we are obligated to keep pushing until we have a growing cluster of cross-discipline, or full-discipline, academic stalwarts. 


\section{Rewards for New Product Development Teams}

\section{Milton D. Rosenau, Jr.}

Devising appropriate rewards to promote cooperative multifunctional teamwork is an unresolved new product development challenge. The subject even has been covered entertainingly in recent nontechnical literature [1]. This challenge is especially prevalent in large established corporations, where much management attention and energy is devoted to running the ongoing business. Frequently, that business is functionally organized, the corporate culture stems from this organization, and an employee's career succeeds or fails in part by his or her functional loyalty. Teamwork may be less of an issue for a small start-up company, where the sole critical activity is getting an initial product to market after which stock options can provide very large financial rewards upon market success.

The challenge is exacerbated by the increased stress on shorter time-to-market $[1,2,7,10-12,15]$. The causes of this include:

1. Explosive technology changes, especially the microcomputer, but increasingly biotechnology, materials, and other technologies, all of which permit improved (or, at least, increased) capabilities; and

2. Instant worldwide communications, which has two impacts:

a. for multinational companies, with team members sharing the development in widely separated time zones, daytime work can proceed virtually without interruption, and

b. news of any innovation is rapidly disseminated, following which competitors may respond quickly.

Without exception, multifunctional teamwork is cited by all observers as a requirement for achieving shorter time-to-market. In fact, any successful new product development effort-fast or slow-requires varied skills contributed by many functional specialties. Unfortunately, the recent staff reductions-socalled "downsizing"-in many large corporations makes many employees less prone to take personal risks, which can exacerbate the need for cooperative multifunctional teamwork.

While corporations stress multifunctional teamwork, they continue to primarily reward individual behavior.
Salary and promotion normally is decided by functional department supervision. I know of one mid-level manager who was designated to lead a multifunctional new product development team. The effort was ultimately unsuccessful, primarily because the strategic choices made by the corporation's senior executives were flawed. Instead of recognizing the team leader's increased knowledge and experience after this effort, his management left him in the corporate "doghouse" for a few years. Many other team members left the corporation. While the team manager's career has since been revived, the "doghouse" message will never encourage - and will probably discourage -risk-taking new product development.

There are isolated examples of rewards for timely multifunctional teamwork:

3M's Industrial Specialties Division provided certificates to all team members if the new product was introduced on or before the target date, and all team members and their spouses were taken to dinner by the division's general manager [6].

Honeywell Space System Group had a cash bonus for timely chip design quality in 1987 [9]. Each design engineer was to receive $\$ 150$ if one chip passed the first design step on schedule, $\$ 500$ if two chips passed on schedule, and $\$ 1,200$ if three passed on schedule. In addition, the entire team was to receive a further $\$ 500, \$ 1,500$, or $\$ 4,000$ if one, two, or three chips passed on schedule, which was to be divided among team members.

The Best Practices study sponsored by the Product Development and Management Association [8] revealed that only $7.4 \%$ of 189 responding companies tie compensation plans to successful performance of new products. Another observer, in a lengthy discussion of new product development rewards [5], says, "The most underdeveloped area of new product management is effective financial rewards and incentive and compensation practices" [p. 228]. This study also points out that teams can be rewarded as well as individuals.

Although not specific to new product development, several corporations provide cash incentives for business profits. These profits clearly depend, in part, on new product development and multifunctional teamwork. Two examples are:

Bausch \& Lomb rewards all employees at a sunglasses plant with a bonus based on the 
plant's profitability. This provides an incentive for everyone to work cooperatively [13].

Another major corporation with diversified business units had a monetary incentive system that rewarded employees for corporate profitability. (I have altered the details to preserve confidentiality.) All employees received an annual cash bonus that depended on the corporation's profits; this was set as a percent of earned wages up to $\$ 10,000$ (with a maximum of a few percent). Employees who earned in excess of $\$ 10,000$ were paid an additional percent of the amount by which their wages exceeded $\$ 10,000$, so an employee who earned $\$ 30,000$ had twice the stake of one who earned $\$ 20,000$; this recognized that more highly compensated employees were presumably more influential in making the corporation profitable. In addition, the most highly compensated managers and executives (about $1 \%$ of the staff) received substantial deferred compensation based on the extent by which the corporation's profits increased over the prior year in excess of a given amount. This system assured that every employee-regardless of their functional department - was sensitive to corporate profit and took cooperative actions to help increase it.

Presumably these approaches are helpful, but they are obviously not applicable to all new product development situations nor-to my knowledgewidely emulated. Thermo Electron stimulates entrepreneurial new products by the "spin-out" of a new business when a promising idea is presented. The new company obtains equity financing from a public stock offering, the advocate receives an equity stake, and Thermo Electron retains a majority stake [16]. Whether this incentive promotes multifunctional teamwork is, however, unclear.

There also are many instances of individual nonsalary rewards: many corporations have an employeeof-the-month, celebratory dinners, plaques to recognize some event, and similar recognitions. In most instances, these are based on a manager's or executive's subjective evaluation of some aspect of performance. Inadvertent inequities can result from such idiosyncratic methods, producing demotivation.

There are issues of equity and equality that must be addressed for whatever multifunctional teamwork reward methods are developed [14]. What does a company do with (and for) essential employees (e.g., the lobby or telephone receptionist whose smile or demeanor affects a key vendor's attitude or the receiving clerk who stays late to accept a critical shipment) who are not truly members of any multifunctional team? What about the various staff and functional support personnel who do work directed by the multifunctional team? Although one approach has been proposed [10, pp. 177-179], it is not easy to implement and I am not aware that it has been adopted. As always, any incentive must be designed to promote the desired behavior. There is always a risk with any reward system that it will produce unintended behavior. No corporation can prosper for the long term by stimulating and rewarding behavior that produces merely minor innovations. Thus, any reward system must accommodate both small short-term and large long-term team efforts - and everything in between. One observer doubts that any incentive plan can work [4], but this does not agree with my personal experience which is that employees pay attention to what management rewards.

As I said at the start of this essay, devising appropriate rewards to promote cooperative multifunctional teamwork is an unresolved new product development challenge. It is unlikely that any single approach will be helpful in all situations, because new product development practices, corporate cultures, products, and development cycles themselves are so varied. Hopefully this essay will stimulate more academic research and practitioners' reports about what has worked-and what has been counterproductive. For instance, if an earlier compensation study sponsored by the Product Development and Management Association [3] is repeated, it would be helpful to discover and report what incentive rewards are now being practiced. Some other questions to examine include:

1. Can rewards consistently promote multifunctional teamwork?

2. What form of reward (e.g., money or other) is most effective?

3. When should rewards be bestowed (especially in multi-year new product development efforts)?

4. Is an objective pre-determined formula or more idiosyncratic executive discretion more effective?

5. Can faimess be maintained?

Thomas P. Hustad provided provocative and helpful comments on an early draft. 


\section{References}

1. Butman, J. FlyingFox: A Business Adventure in Teams and Teamwork, New York: AMACOM, 1993. Reviewed in Journal of Product Innovation Management, 11:89-90 (1994).

2. Clark, K. B. and Fujimoto, T. Product Development Performance: Strategy, Organization, and Management in the World Auto Industry. Boston: Harvard Business School Press, 1991. Reviewed in Journal of Product Innovation Management, 9:85-86 (1992).

3. Feldman, L. P. A profile of the new product professional, Journal of Product Innovation Management 8:252-266 (1991).

4. Kohn, A. Why incentive plans cannot work. Harvard Business Review, Sept.-Oct.:54 (1993).

5. Kuczmarski, T. D. Managing New Products, 2nd ed. Englewood Cliffs, NJ: Prentice Hall, 1992, pp. 228-240. Reviewed in Journal of Product Innovation Management 9:260-261.

6. McKeowen, J. J. New products from new technologies. Journal of Business \& Industrial Marketing, Winter/Spring:67-72 (1990).

7. McGrath, M. E., Anthony, M. T. and Shapiro, A. R. Product Development: Success Through Product And Cycle-Time Excellence. Stoneham, MA: Butterworth-Heinemann (Reed Publishing), 1992. Reviewed in Journal of Product Innovation Management 10:264-265 (1993).

8. Page, A. L. Establishing crucial new product norms. Journal of Product Innovation Management 10:273-290 (1993).
9. O'Dell, C. Team play, team pay-new ways of keeping score. Across the Board, Nov. 1989, pp. 38-45.

10. Rosenau, M. D. Faster New Product Development: Getting the Right Product to Market Quickly, New York: AMACOM, 1990. Reviewed in Journal of Product Innovation Management 7:336-337 (1990) and Visions, Oct:5 (1990).

11. Rosenthal, S. R. Effective Product Design and Development: How to Cut Lead Time and Increase Customer Satisfaction, Homewood, IL: Business One Irwin, 1992. Reviewed in Journal of Product Innovation Management, 9:327-328 (1992).

12. Smith, P. G. and Reinertsen, D. G. Developing Products in Half the Time. New York: Van Nostrand Reinhold, 1991. Reviewed in Visions, Feb: 11 (1991).

13. Stem, A. Managing by team is not always as easy as it looks. The New York Times, July 18, 1993, p. F5.

14. Sykes, H. B. Incentive Compensation for Corporate Venture Personnel. Journal of Business Venturing 253-265 (1992); abstract in Journal of Product Innovation Management 10:171-172 (1993).

15. Wheelwright, S. C. and Clark, K. B. Revolutionizing Product Development: Quantum Leaps in Speed, Efficiency, and Quality, New York: The Free Press, 1992. Reviewed in Journal of Product Innovation Management 10:87-88 (1993).

16. Wilke, J. R. Innovative Ways: Thermo Electron Uses an Unusual Strategy to Create Ptoducts. Wall Street Journal, Aug. 5, 1993, p. 1. 